\title{
MATERIALY
}

TOMASZ JUREK (Instytut Historii Polskiej Akademii Nauk, Poznań) https://orcid.org/0000-0003-4519-0883

\section{Wilkierz rady miasta Wolsztyna z 1471 roku}

Zarys treści: Uchwalane w miastach rządzących się prawem niemieckim statuty (Willküre) znane są głównie z miast dużych. Artykuł przynosi publikację tekstów pochodzących z małego miasta Wolsztyn w Wielkopolsce: zatwierdzenia przywilejów przez dziedzica miasta (1469) oraz staututu przyjętego przez radę (1471).

\begin{abstract}
The statutes (Willküre) of towns founded on German law are known mostly from large cities. This paper contains an edition of texts from a small town of Wolsztyn (Wollstein) in Great Poland: confirmation of privileges by the owner of the town (1469) and the statute accepted by the town council (1471).
\end{abstract}

Słowa kluczowe: wilkierz, Wolsztyn/Wollstein, przepisy przeciwpożarowe

Keywords: town statutes, Willkür, Wolsztyn/Wollstein, fire-fighting regulations

Mianem wilkierza, pochodzącym od niemieckiego słowa Willkür (złożenie z Wille oraz Kür), oznaczającego właściwie „wolny wybór”, ale w praktyce prawnej swobodnie podjętą decyzję, określa się u nas normatywne postanowienie władz miejskich. Pojęcie przyniesione zostało na ziemie polskie wraz z obowiązującym w miastach prawem niemieckim. Równorzędnikiem bywał też termin „kiere” (użyty choćby w niżej publikowanym tekście), czyli tyle, co samo Kür (wybór, decyzja). To gatunek tekstów prawnych występujących powszechnie we wszystkich miastach, ale zarazem nierównomiernie zachowany i nie najlepiej rozpoznany ${ }^{1}$. Znane są przede wszystkim wilkierze z dużych ośrodków miejskich, gdzie wydawano je najwcześniej oraz najczęściej i gdzie były też najstaranniej przechowywyane. Gromadzono je nawet w osobnych zbiorach ${ }^{2}$. Postanowienia władz mniejszych miast są słabiej

${ }^{1}$ A. B a rto s z e w i c z, Piśmienność mieszczańska w późnośredniowiecznej Polsce, Warszawa 2012, s. 115-118; t a ż, Urban Literacy in Late Medieval Poland, Turnhout 2017, s. 154-158. Dla samego pojęcia, mającego centralne znaczenie w germańskiej tradycji prawnej, zob. F. E b e l, Willkür, w: Lexikon des Mittelalters, t. IX, 1999, kol. 217-218.

${ }^{2}$ M. S t a r z y ń s k i, Krakowska rada miejska w średniowieczu, Kraków 2010, s. 100 n., 305-336 (zestawienie 115 wilkierzy krakowskich z lat 1336-1500); t e n ż e, Das mittelalterli- 
poświadczone, przeważnie dopiero z czasów nowożytnych. Zapewne wiele starszych poginęło, tym bardziej że z biegiem czasu mogły się dezaktualizować. Piętnastowieczne zabytki pochodzące $\mathrm{z}$ mniejszych miasta polskich nie są w każdym razie częste, aczkolwiek może to być też efektem niedostatecznej wciąż kwerendy archiwalnej. Ciekawym, ale i wyjątkowym w skali ziem polskich, pomnikiem pozostają zbiorki kilku wilkierzy wydanych przez władze małopolskiego Czchowa i Pilzna ${ }^{3}$. Wobec owego ubóstwa znanych tekstów z małych miast każdy nowy zabytek uznać należy za ważny i interesujący.

Niniejszym publikuję wilkierz pochodzący z Wolsztyna (niem. Wollstein), położonego nad Obrą, na południowo-zachodnich kresach Wielkopolski ${ }^{4}$. Była to stosunkowo późna lokacja prywatna. Miasto założył ok. 1420 r. Marcin Sepieński na gruntach nabytej kilka lat wcześniej wsi Komorowo. Miasto nie rozwijało się świetnie. Na wyprawę pod Malbork w 1458 r. wysłać miało 4 zbrojnych, co plasuje je w szeregu miasteczek o lokalnym znaczeniu. Słabo zachowane są też miejskie archiwalia. Nie znamy dziś przywileju lokacyjnego. Księgi miejskie zachowały się dopiero z XVI w.: radzieckie od 1539, ławnicze natomiast od 1552 r. ${ }^{5}$ Na początku pierwszej księgi radzieckiej znajdujemy jednak starszy fragment. Otwiera ją mianowicie (k. 2r) nota inauguracyjna opowiadająca o odbytym 21 I 1469 r. w domu rajcy Jana Czecha posiedzeniu rady, podczas którego w obecności dziedzica Andrzeja Sepieńskiego ${ }^{6}$ założono „księgę miasta Wolsztyna, zawierającą prawa magdeburskie przyjęte już wcześniej za zwyczaj w Królestwie Polskim i zachowywane, aby cokolwiek w niej zostało postanowione, miało taką moc, jakby zostało osądzone i ustanowione w samym mieście Magdeburg”. Nie jest całkiem jasne, czy zakładana księga miała

che Krakau. Der Stadtrat im Herrschaftsgefüge der polnischen Metropole, Köln-Weimar-Wien 2015, s. 78 n., 165-193; Wilkierze poznańskie t. I-III, wyd. W. Maisel, Wrocław 1966-1969; Materiały do monografii Lublina. Wikierze XV-XVII w., wyd. L. Białkowski, Lublin 1928; T. Maci ejewski, Wilkierze miasta Torunia, Poznań 1997; t e nże, Ustawodawstwo wilkierzowe miast regionu gdańskiego i jego stosunek do prawa chełmińskiego, w: Studia Culmensia historico-iuridica, czyli Księga pamiątkowa 750-lecia prawa chełmińskiego, t. II, Toruń 1988, s. 337-363; W. Ma is e 1, Kodyfikacje statutów miejskich w dawnej Polsce, Studia Źródłoznawcze 22, 1977, s. 151-166.

3 Bibliografię starszych wydań zestawił S. K u tr z e b a, Historia źródeł dawnego prawa polskiego, t. II, Lwów 1926, s. 198-199, 244-246; zob. B. W y r o z u m s k a, Najstarsze uchwały miejskie (wilkierze) Czchowa, przedruk w: tejże, Fontes. Prace wybrane z dziejów średniowiecza i nauk pomocniczych historii, Kraków 2018, s. 31-51 (gdzie wydanie 15 wilkierzy z lat 1425-1559, a na s. 34, przyp. 19, uzupełnienia do bibliografii edycji); A. B a r t o s z e w i c z, Piśmienność, s. 117 (informacja o wilkierzach z Pilzna).

${ }^{4}$ O historii miasta S. K a r w o w s k i, Wolsztyn i jego dziedzice, Poznań 1911, a ostatnio stosowne hasło w Słowniku historyczno-geograficznym województa poznańskiego w średniowieczu, cz. V, Poznań 2012-2019, s. 821-833.

${ }^{5}$ Poznań, Archiwum Państwowe, Akta miasta Wolsztyna I/1 (księga radziecka), I/6 (księga ławnicza). Najstarszych ksiąg nie znał jeszcze A. Wa r s c h a u e r, Die städtischen Archive in der Provinz Posen, Leipzig 1901, s. 275-276.

${ }^{6}$ Andrzej Sepieński zwany Sędzicem był synem Jakuba, sędziego poznańskiego 14521464 (zm. 1464/1465), który kupił Wolsztyn w 1438 r. od swego bliżej nieokreślonego krewnego, Marcina Sepieńskiego, założyciela miasta; Andrzej występował w 1. 1465-1472, zmarł 1472/1473, a dobra wolsztyńskie przeszły na jego córki i ich mężów (Słownik historyczno-geograficzny, cz. V, s. 823). 
służyć zapisaniu norm prawa magdeburskiego, czy też dokonań miejscowej jurysdykcji miejskiej. Zaraz potem (k. 2r-2v) wciągnięto datowany na ten sam 1469 r. dokument dziedzica Andrzeja, odnawiający prawa miejskie, stracone w zaszłym tegoż roku pożarze miasta, który „obrócił je w niwecz”. Obie decyzje - założenie księgi i odnowienie przywileju - zapadły najpewniej równocześnie i nie ulega wątpliwości, że stały w związku z usuwaniem skutków katastrofy, która dotknęła miasto. Być może istniała zatem starsza jeszcze księga miejska, która przepadła w ogniu. Bezpośrednio po przywileju dziedzica (k. 2v-3r) wpisano interesujący nas wilkierz, uchwalony przez radę za zgodą tego samego Andrzeja Sepieńskiego w 1471 r. Dalej (w ciągu, od k. 3v) biegną w księdze wpisy działań rady z 1539 r. i lat następnych. Nota inauguracyjna, przywilej dziedzica i wilkierz wpisane zostały niewątpliwie tą samą ręką, która prowadziła potem kolejne wpisy czynności rady. Zapisu dokonano zatem na pewno w 1539 r. Przepisano jednak owe trzy starsze fragmenty. Musiały one pochodzić ze starszej, obecnie zaginionej księgi miejskiej, tej którą rajcy założyli w styczniu 1469 r. Trudno wyjaśnić, dlaczego tak postąpiono. Można zrozumieć, że zakładając nową księgę dla czynności rady, postanowiono na jej początku umieścić podstawowe akty prawne (także we wspomnianym Pilznie wilkierze otwierały nową ksiegę) - ale nie wyjaśnia to, czemu skopiowano też notę o założeniu księgi z 1469 r. Być może pisarz postąpił tu całkiem bezrefleksyjnie i mając skopiować fragment poprzedniej księgi, uwzględnił też niepotrzebnie notę początkową.

Interesujący nas wilkierz ma bardzo prostą konstrukcję i formularz, typowe dla tekstów tego rodzaju ${ }^{7}$. Zaczyna się od daty (zredukowanej zresztą do podania samego roku, bez wymienienia dnia i miejsca) oraz wystawcy. Ten ostatni opisany został zresztą tak niezdarnie, że dosłownie rzecz biorąc, mowa jest tylko o zgodzie dziedzica i rajców na decyzję podjętą nie wiadomo przez kogo. Wydaje się, że sytuacja ta nie jest czysto przypadkowa, lecz oddaje rozterki pisarza, który jakby nie wiedział do końca, czy to dziedzic stanowił normy za zgodą rady, czy rada za zgodą dziedzica. Potem następują kolejne punkty podjętych postanowień „,przeciwko tym, którzy przekraczają [wyznaczone] granice". Tekst pisany jest po łacinie (w większych miastach często używano niemieckiego), językiem bardzo prostym - z reguły w schemacie: kto popełni pewien uczynek, ten winien zapłacić karę. Mimo tej prostoty tekst nie zawsze jest (jak pokazuje nie tylko sprawa wystawców) poprawny gramatycznie; pełno jest błędów, pomyłek fleksyjnych, niezręczności, przekręconych słów itp. Domyślać się można, że to dzieło jakiegoś miejscowego duchownego - może plebana, może zaś rektora szkoły parafialnej (który w mniejszych miastach pełnił często także funkcję pisarza miejskiego). Pamiętać jednak trzeba, że za część błędów (np. zdarza się też gubienie pojedynczych liter) odpowiadać mógł jednak szesnastowieczny kopista.

Zawartość postanowień jest bogata i różnorodna ${ }^{8}$. Miejski ustawodawca rozważał rozmaite sprawy porządkowe. Nieprzypadkowo po wielkim pożarze sprzed dwóch lat jako punkt pierwszy przypomniano wymóg, by ogłaszać zauważony ogień (1).

${ }^{7}$ Zob. zwłaszcza przykłady czchowskie (B. Wy r o z u m s k a, Najstarsze uchwały, s. 37 n.).

${ }^{8}$ Dokument streścił S. K a rw o w s k i, Wolsztyn, s. 6-8, powołujący się na jakiś nowożytny odpis; dokładne streszczenie: Słownik historyczno-geograficzny, cz. V, s. 827-828. O wolsztyńskim wilkierzu wspominał też J. K r a s o ń, Zbąszyń do przełomu wieku XVI-go i XVII-go, Zbąszyń 1935, s. 66-67. 
Kwestie przeciwpożarowe wróciły też dalej, w punkcie mówiącym o obowiązku utrzymywania przy każdym domu odpowiedniego sprzętu gaśniczego, czyli drabiny i wody (17). Najwięcej miejsca poświęcono sprawom porządkowym i kryminalnym. Już w nagłówku zapowiadano, że chodzi o przepisy skierowane przeciwko przestępcom. Potem enumerowano różne przypadki wykroczeń, jak napaść na dom (2), wydobycie przeciw komuś miecza lub innej broni $(4,5)$, rzucanie w kogoś siekierą lub innym groźnym narzędziem (6), uderzenie nożem (7), wyrywanie włosów, a może samo targanie za włosy (8), obraźliwe słowa, co wyraźnie ograniczano do kłótni kobiet (9), wyrządzanie szkód w ogrodzie (10), niszczenie płotu (11), wchodzenie z bronią do karczmy (13). Osobno wymieniono niszczenie urządzeń publicznych znajdujących się na rynku lub beczek stojących przed domami (12). Znaczenie porządkowe miały też wymogi udzielania pomocy na wezwanie (3) i stawiania się na bicie w dzwon miejski (14). Niejasny pozostaje przepis wymagający od rajców, by podążali zaraz za woźnym (16). Zakazywano sięgania po sprawiedliwość wprost do „,jakiegoś” (a więc chyba obcego) dziedzica, bez uprzedniego skarżenia się rajcom (15). Zakazywano obrażania ławników idących w celu wypełnienia swych funkcji urzędowych (20). Nie wolno było posiadać niewłaściwych naczyń i miar $(18,19)$. Były wreszcie sprawy obyczajowe - grożono karami za przyjmowanie w domu „łotrów i nicponiów” w piątki lub dni świątecznie oraz picie z nimi przed mszą (21), a także grę w kości i karty lub picie po nocach, zwłaszcza w wigilie świąt i same święta (22). Przepisy te rysują bardzo ciekawy obraz życia codziennego miasta i jego mieszkańców oraz trapiących ich bolączek. Jest tu dużo ciekawych szczegółów. Nie sposób tu wszystkiego omawiać, ale wskażmy choćby kilka spraw. Dla obrazu miasta ważne są wzmianki o urządzeniach na rynku, gdzie stały ławy (scamna), studnia, jakieś słupy na rogach oraz „rury rozciągnięte do picia” (chyba poidła dla zwierząt?). Ciekawe są informacje o grze w kości i karty oraz o piciu gorzałki. I karty, i gorzałka przyjmowały się u nas stopniowo w ciągu XV w. (warto przy tym podkreślić, że kanoniczny termin crematum dopisano dopiero później nad skreślonym pierwotnym sublimatum, co było określeniem zgoła nieszablonowym, a więc pisarz w 1471 r. nie znał jeszcze właściwego słowa). Padają specyficzne określenia rodzajów broni, jak siekierka (securcellum), którą można było uderzać lub rzucać w sąsiada albo też rąbać sprzęty, deka (rodzaj noża), sarmata czy zwłaszcza pizdygan ${ }^{9}$ - zdaje się, że to lokalna oboczność słowa buzdygan, której używanie utrwalone jest zresztą w nazwisku mieszczanina Kaspra Pizdygana, znanego od 1542 r. kowala, burmistrza w 1546 , a rajcy w latach $1547-1550^{10}$.

Geneza wilkierza wydaje się jasna. Wiązał się z odbudową miasta po pożarze. Ogień strawił być może jakieś poprzednie uchwały miejskie, które należało odnowić. Przede wszystkim zaś miasto po katastrofie przeżywało chyba czas zamętu. Trudności pokazuje potwierdzenie praw miejskich przez dziedzica z 1469 r. Wymaga on,

9 Słów sarmata i pizdygan nie znają Słownik staropolski (t. VI, Wrocław 1970-1973, t. VIII, Wrocław 1977-1981), ani Słownik polszczyzny XVI wieku (t. XXIV, Warszawa 1996). A. B r ü c kne r, Słownik etymologiczny języka polskiego, Kraków 1927, s. 51, wyjaśnia, że buzdygan pochodzi od tureckiego bozdogan, czyli 'pałka', a ,postaci tego słowa u innych Słowian zmienne”. Może więc wolsztyński pizdygan to zwykła pałka.

${ }^{10}$ Słownik historyczno-geograficzny, cz. V, s. 825, 828. 
aby władze miasta ukróciły gwałty, rozsądnie zalecając, by winowajców nie karać śmiercią lub wygnaniem - co wynikało raczej nie tyle z humanitaryzmu, ile z obawy przed uszczupleniem liczby mieszkańców. Mieszczanom dano jednak władzę karania złych i oddzielenia ich od dobrych. Zdaje się nie ulegać wątpliwości, że realizację tych życzeń i wskazań dziedzica stanowił właśnie nasz wilkierz. Poświęcony został w lwiej części sprawom przywrócenia w mieście bezpieczeństwa. Rzeczywiście też oszczędnie operował karą śmierci, zastrzeżoną tylko dla jednej zbrodni - napaści na dom (2), co stanowić musiało widocznie największy problem. Dominowały kary pieniężne, konfiskować miano używaną do przestępstw broń, zaś za niszczenie ogrodów groziło obcięcie ucha (10).

Różnorodność rozważanych spraw - obok siebie stoją postanowienia kryminalne, porządkowe, przeciwpożarowe czy obyczajowe - jest typowa dla wilkierzy małych miast. Świadczy to o rzadkim uchwalaniu takich aktów, które zbierały wówczas rozmaite sprawy. Specyfikę tę oddają też umieszczone pod wolsztyńskim tekstem dodatki. Mianowicie dopisano tam później jeszcze dwa punkty $(23,24)$, regulujące zasady handlu solą - nie wolno jej było kupować od wozaków między południem piątkowym a południem sobotnim, kobietom zaś (miejscowym) nie wolno było sprzedawać jej przed biciem w dzwony. Punkty te dopisane zostały inną ręką niż całość tekstu, a więc innego pisarza niż ten, który zakładał w 1539 r. i prowadził potem księgę radziecką. Rękę dopisującą przepisy solne odnajdujemy w księdze nieco później - w latach 1544 (k. 10), 1546 (k. 13-14) i 1548 (k. 17, gdzie powtarzają się bardzo charakterystyczne znaczki nad literą $u$ ). Pokazuje to, że dopiski nie oznaczają zwykłej korekty, ale uzupełnienie dodane kilka lat po wpisaniu zasadniczego trzonu tekstu. To bardzo ważna konstatacja. W związku z pojawieniem się nowego problemu nie uchwalano mianowicie nowego wilkierza, ale uzupełniono po prostu stary tekst. Widzimy zarazem, że uzupełniany wpis w księdze stanowił podstawowy środek transmisji treści wilkierza. Można mieć wątpliwości, czy wilkierz nasz funkcjonował w ogóle kiedykolwiek w postaci „oryginału”, spisanego na osobnej karcie i opieczętowanego. Już w chwili uchwalenia ograniczono się zapewne do wpisu do księgi miejskiej, który skopiowano następnie przy zakładaniu nowego woluminu akt radzieckich w 1539 r.

\section{TEKST ŹRÓDŁOWY}

Poniżej publikuję nie tylko sam wilkierz, ale wszystkie trzy teksty otwierające najstarszą księgę radziecką (Akta miasta Wolsztyna I/1, k. 2-3), w przekonaniu, ze stanowią one pewną integralną całość. Tekst oddany został zgodnie z zasadami A. Wolffa, Projekt instrukcji wydawniczej dla pisanych źródeł historycznych do połowy XVI wieku, Studia Źródłoznawcze 1, 1957, s. 155-181, nawiązującymi zresztą do Instrukcji wydawniczej PAU z 1925 r. Rezygnuję z przypisów rzeczowych pewne osoby i okoliczności zostały objaśnione wyżej, o większości wymienionych mieszczan nie da się nic powiedzieć, a poza tym wzmiankowane są tylko okoliczne miejscowości: Komorowo (gdzie znajdował się kościół św. Katarzyny), Byrzyna i Niałecki Młyn. 
A. Nota inauguracyjna księgi miejskiej, 21 I $1469 r$.

Anno Domini millesimo quadringentesimo sexagesimo nono die dominica Adorate in festo sacratae virginis Agnetis in domo consulis Johannis Czech tunc temporis sedentibus proconsule Myklasz unacum consulibus Johanne Czech, Johanne Kvsz, Nicolao Szwyethllyk, antiquo Jacobo, Niger Hanus, Petro sartore et domino Andrea Szepyenszky herede in Volsthyn residentibus in eodem domo insimul et aliis quamplurimis fidedignis existentibus inceptus est liber civitatis Volsthyn continens in se iura Madburgensia pro consuetudine in Regno Polonie iam pridem recepta et observata, nam quidquid de eisdem libris decretum fuerit, hoc fiet firmum et di(i)udicatum, quasi in eadem civitate Maydburg esset iudicatum ac firmatum.

\section{B. Przywilej dziedzica z $1469 \mathrm{r}$.}

In nomine Domini amen. Cunctorum eternorum ne pereat memoria, litterarum et sigillorum firmitate sollent communiri. Proinde nos Andreas de Sepno heres in Volsthyn recognosco publice per praesens scriptum omnibus et singulis, quibus necesse fuerit, praesentibus et futuris, quomodo anno Domini millesimo quadringentesimo sexagesimo nono ex permissione Dei hec nostra civitas in nichilum redacta per ignem fuerat totaliter et combusta, tunc nostri cives cupientes iur(i)um suorum per nos conservare robur totaque civitas congregati nostram presentiam accesserunt cogitantes postularuntque a nobis herede praedicto habere privilegium perpetue firmitatis. Egoque praefatus Andreas in Wolsthyn heres praefatorum meorum civium, proconsulis, consolum [!] toteque comunitatis praedicte civitatis mee Volsthyn attenta petitione iusta et rationi consona et iuste petentibus assensus non est denegandus, hunc [!] meum praesens privilegium meo sigillo roboratum eisdem civibus meis contuli in his scriptis, queque civitas mea dicta Volsthyn in districtu Costensi est situata. Quod privilegium habere et perpetue manere volo nunc et (pro?) meis successoribus, ut ipsi cives nostri possideant bona nostra in dicta nostra hereditate existentia, videlicet agros, ortos, piscinas, prata et in eis gramina cum omnibus eorum attinentiis, tam late secundum quod aliquis eorum est vel fuerit sibi emptus. Damus etiam eidem oppido nostro ius Madburgense, damus $[k .2 v][\ldots \ldots \ldots \ldots \ldots \ldots \ldots \ldots \ldots . . . . \ldots \ldots$ ui iura, quae ante combustionem dicte $\mathrm{n}[$ ostre c]ivitat[is habeb]ant et possidebant. Damus eciam eisdem $^{b-b}$ civibus nostris ortos incipendo ab orto plebani in Comorowo recta via de civitate transeundo ante ecclesiam sanctae Katherinae virginis et martiris gloriosae usque ad granicies ville Byrzyna dicte et ad usque molendinum dictum Nyalczesky et insuper ortos in dextra parte de dicto oppido nostro Volsthyn transeundo penes lacum et usque ad granicies ville Chorzemyno dicte. Insuper damus eisdem civibus nostris dicte nostre civitatis Volsthyn forale alias targowe ab istis, qui aliunde ad forum pro emendis frumentibus, a quolibet curru grossum vel secundum quod iusticia exposcet. Insuper statuo eisdem civibus nostris Volstyn censum balneatoris pro melioracione dicti oppidi nostri Volsthyn. Ecciam donavimus dictis nostris civibus, quod nullus plebanus sine voluntate domini sive heredis et voluntate dictorum nostrorum civium rectorem schole suscipere audeat. Insuper damus nostris civibus, quod ipsi nunquam violenciam aliqaum admittant in dicto oppido nostro, si vero aliquis temerarie hospes vel saltim hanc nostram civitatem inhabitans violenter fecerit, super eundem mere debito proclametur non interficiatur, sed detineatur, detentumque quod iuris fuerit 
condempnetur. Si vero talis interfectus fuerit, huius nulla sit memoria. Insuper damus nostris civibus potestatem malos corrigendi et eradicare malos a bonis. Ecciam dictis nostris civibus mandamus unicuique iusticiam administrare. Insuper dictis nostris civibus dicte nostre civitatis Volsthyn hunc meum privilegium volumus permanere in vigore tali, prout et pristini privilegii tenor canebat. Praesentibus ibidem providis Myklasz proconsule nec non consulibus Johanne Czech, Johanne Kvsz, Nicolao Szwyethlyk, Jacobo antiquo, Johanne Nigro, Petro sartore et aliis quamplurimis fidedignis testibus ad praemissa. In cuius rei testimonium sigillum meum presentibus est subapensum. Actum et datum in Volsthyn anno ${ }^{c-c}$ Domini milessimo quadringentesimo sexa(gesimo) IX.

\section{Wilkierz z $1471 \mathrm{r}$.}

Anno Domini millesimo septuagesimo primo. Cum consensu domini Andree Volsthynsky nec non ${ }^{d-}$ cum consensu proconsulis Petro sartore et eciam consulibus, domino Stanislao lanio, Johanne Czech, Myklasz fabro, Laurencio panifice, Hanus Niger, Jacobo Kakyel nec non iuratis omnibus ${ }^{-e}$, qui tunc temporis fuerunt, simul statuerunt super se et super omnes, qui manent in oppido, statuta alias kyere super hos, qui excedunt limites.

[1] In primis statuimus, quod absit, si ignis exiret a vicino et non proclamaret, talis luget penam une sexagene, et si alter vicinus, si videret ignem exeuntem a suo vicino et proclamaret, tunc talis est excussatus a pena.

[2] Item statuimus, si quis intraret violenti manu super domum alicuius, nihil aliud sibi constat, nisi collum privacionis.

[3] Item statuimus, dum aliquis nostrorum vicinorum proclama[ $k$. 3] ret ad violenciam et alter videns et audiens non transsiret ad adiuvandum, tun(c) talis dabit e $(\mathrm{t})$ tenetur sexagenamf.

[4] Item si aliquis vicinus super alium evaginans gladium, iste perdet gladium et tenetur dare fertonem ad pretorium.

[5] Item si aliquis evaginans sarmatam super aliquem vel vicinum, tunc iste tenetur dare sex grossos et perdet sarmatam.

[6] Item si aliquis proiciens super aliquem securcello, talis tenetur dare fertonem, vel aliqua proiectura galky vel pysdyganem vel aliquo huiusmodi tello sex grossos tenetur dare, vel bacculo si aliquis alium percussiset, talis tenetur fertonem.

[7] Item si aliquis voluisset aliquem transfodere cultello vel deką, iste est di(i)udicatus ab honore et sexagenam tenetur dare.

[8] Item dum depilati essent aliqui, tales tenentur per sex grossos dare.

[9] Item dum alique due vicine insurexissent in se verbis malignis et esset testimonium super aliaquam, tunc una, que esset contraria, tenetur dare tres grossos vel sedere in sporta. [10] Item si aliquis intraret in ortum alicuius sine licencia et damnum faceret vel aliquid rueret, seccaret, talis debet dare fertonem vel aure privari.

[11] Item si aliquis sepes seccaret vel caperet, talis tenetur dare fertonem.

[12] Item si aliquis transiens per circullum et secaret securcello aut gladio aut aliquo tello scamna, piscina aut fontem vel statutas circa angiportum vel virgas, que ad potum sunt extense, aut aliquot vasum stantem ante domum alicuius vicini, talis tenetur dare sex grossos. 
[13] Item si aliquis iret ad tabernam cum gladio, securi aut aliquo huiusmodi tello, talis tenetur dare tres grossos et illud tellum perdet.

[14] Item statuimus, si aliquis vicinus non iret ad consulem, dum tercio signatur ad campanam civilem vel dum proclamatur, talis tenetur tres grossos dare.

[15] Item statuimus, si aliquis ex vicinis recursum haberet conquerens ad aliquem coram herede aliquo et non esset petitus ad consulem cum querela, talis tenetur dare sexagenam.

[16] Item dum aliquis consul non iret statim post preconem, talis mediente carebit. [17] Item dum non staret circa aliquem vicinum scala circa domum vel ecciam si aqua non esset circa edes, talis tenetur dare tres grossos.

[18] Item dum ad aliquem civem nostrum esset reperta anphora non iusta et esset testimonium verificum in eundem, talis tenetur dare sex grossos.

[19] Item ecciam, si mensura aut manuale vel huiusmodi aliquid esset inventum ad aliquem et non esset iustum, talis tenetur dare tres grossos.

[20] Item statuimus, quod si aliquando contingeret, quod iurati ambularent per aliquot negocium vel per tributum insimul omnes et si aliqua persona insurrexisset verbis flagiciossis super illos clamando post illos, talis tenetur dare tres grossos sine peticione. [21] Item statuimus, si aliquis ex vicinis nostris admisisset in domo propria latronibus, nebulionibus feriis sextis aut diebus festis ante missam crematum ${ }^{g}$ bibere et erit approbatum ad illum, talis tenetur dare sex grossos.

[22] Item statuimus, si aliquis ex vicinis nostris admisisset in domo propria lussum tesserorum aut cartharum aut alios ludos inhonestos admississet aut potum dare ad mediam noctem his qui bibunt, et precipue in vigili(i)s sanctorum et precipue solemnibus, talis tenetur dare sexagenam ad pretorium sine ulla peticione.

[Dopisane późniejsza ręka z XVI w.:]

[23] Item statuimus, ut nullus audeat ex vicinis nostris emere sal a vectoribus feria sexta a meridie usque ad meridiem die sabbati sub pena sex grossorum.

[24] Item, ut nulla vicina audeat vendere sal ante pulsandum campane civilis sub pena sex grossorum.

${ }^{a}$ Urwany narożnik karty, ${ }^{b-b}$ następuje skreślone: eisdem, ${ }^{c-c}$ następuje wydrapane: ut supra, d-e fragment błędny gramatycznie, powinno być albo: consencientibus proconsule Petro itd., albo: cum consensu proconsulis et eciam consulum, domini Stanislai lanionis, Johannis Czech, Myklasz fabri, Laurencii panificis, Hanus Nigri, Jacobi Kakyel nec non iuratorum omnium, ${ }^{f}$ poprawione $z$ : sexagesima, ${ }^{g}$ nadpisane inna ręka nad skreślonym: sublimatum.

\section{BIBLIOGRAFIA}

Bartoszewicz A., Piśmienność mieszczańska w późnośredniowiecznej Polsce, Warszawa 2012. Bartoszewicz A., Urban Literacy in Late Medieval Poland, Turnhout 2017.

Brückner A., Słownik etymologiczny języka polskiego, Kraków 1927.

Ebel F., Willkür, w: Lexikon des Mittelalters, t. IX, 1999.

Karwowski S., Wolsztyn i jego dziedzice, Poznań 1911.

Krasoń J., Zbąszyń do przełomu wieku XVI-go i XVII-go, Zbąszyń 1935.

Kutrzeba S., Historia źródeł dawnego prawa polskiego, t. II, Lwów 1926.

Maciejewski T., Ustawodawstwo wilkierzowe miast regionu gdańskiego i jego stosunek do prawa chełmińskiego, w: Studia Culmensia historico-iuridica, czyli Księga pamiątkowa 750-lecia prawa chełmińskiego, t. II, Toruń 1988. 
Maciejewski T., Wilkierze miasta Torunia, Poznań 1997.

Maisel W., Kodyfikacje statutów miejskich w dawnej Polsce, Studia Źródłoznawcze 22, 1977.

Słownik historyczno-geograficzny województa poznańskiego w średniowieczu, cz. V, Poznań 2012-2019.

Słownik polszczyzny XVI wieku, t. XXIV, Warszawa 1996.

Słownik staropolski, t. VI, Wrocław 1970-1973, t. VIII, Wrocław 1977-1981.

Starzyński M., Krakowska rada miejska w średniowieczu, Kraków 2010.

Starzyński M., Das mittelalterliche Krakau. Der Stadtrat im Herrschaftsgefüge der polnischen Metropole, Köln-Weimar-Wien 2015.

Warschauer A., Die städtischen Archive in der Provinz Posen, Leipzig 1901.

Wyrozumska B., Najstarsze uchwały miejskie (wilkierze) Czchowa, przedruk w: tejże, Fontes.

Prace wybrane z dziejów średniowiecza i nauk pomocniczych historii, Kraków 2018.

\section{The statut (Willkür) of the town council of Wolsztyn from 1471}

\section{Summary}

The term Willkür denotes normative resolutions of municipal authorities on the basis of German law. On Polish lands such texts are known mainly from large cities (Cracow, Gdańsk, Torun, Poznań), but rarely survive from smaller towns. The paper contains an edition of the statutes accepted in Wolsztyn (German: Wollstein), in the Western part of Great Poland, a relatively small town, founded only in the $15^{\text {th }} \mathrm{c}$. After the fire of the town in 1469 , its owner issued a confirmation of the burnt municipal privileges, ordering the town authorities to reinstate order and safety. The wilkierz of 1471 is devoted to that purpose, containing rules against those, who demolished order, along with fire-fightling and customs regulations. The texts contains specific terms, probably reflecting local customs. The texts of the wilkierz and the privilege survive in the municipal records of 1539, but they were rewritten there from an earlier book of records, started right after the fire of 1469. Adding to the wilkierz some new entries in the 1540s shows that this particular version was the main form of the transmission of the text. 


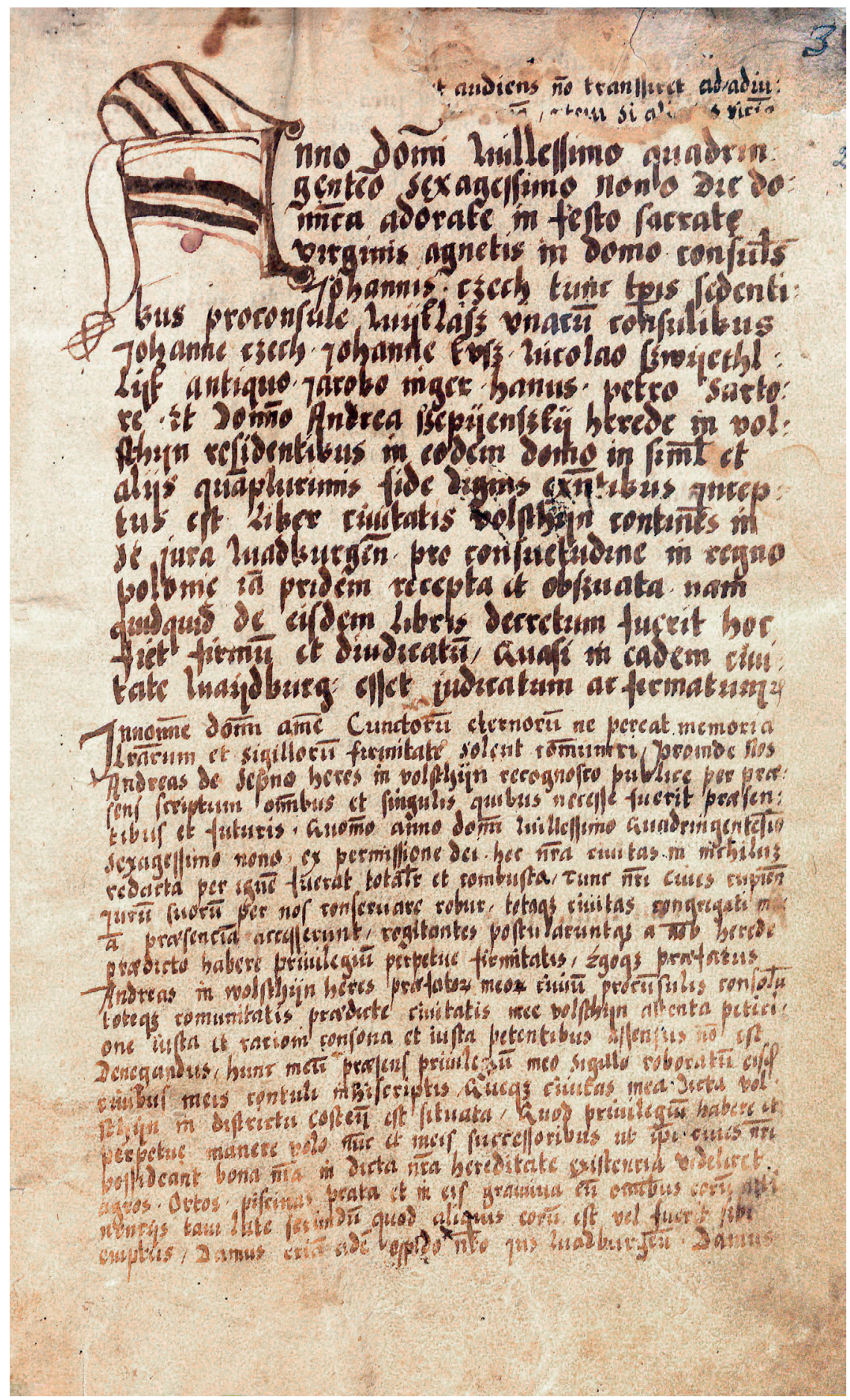

1. Poznań, Archiwum Państwowe, Akta miasta Wolsztyna I/1, k. 2 (nota inauguracyjna i początek przywileju dziedzica) 


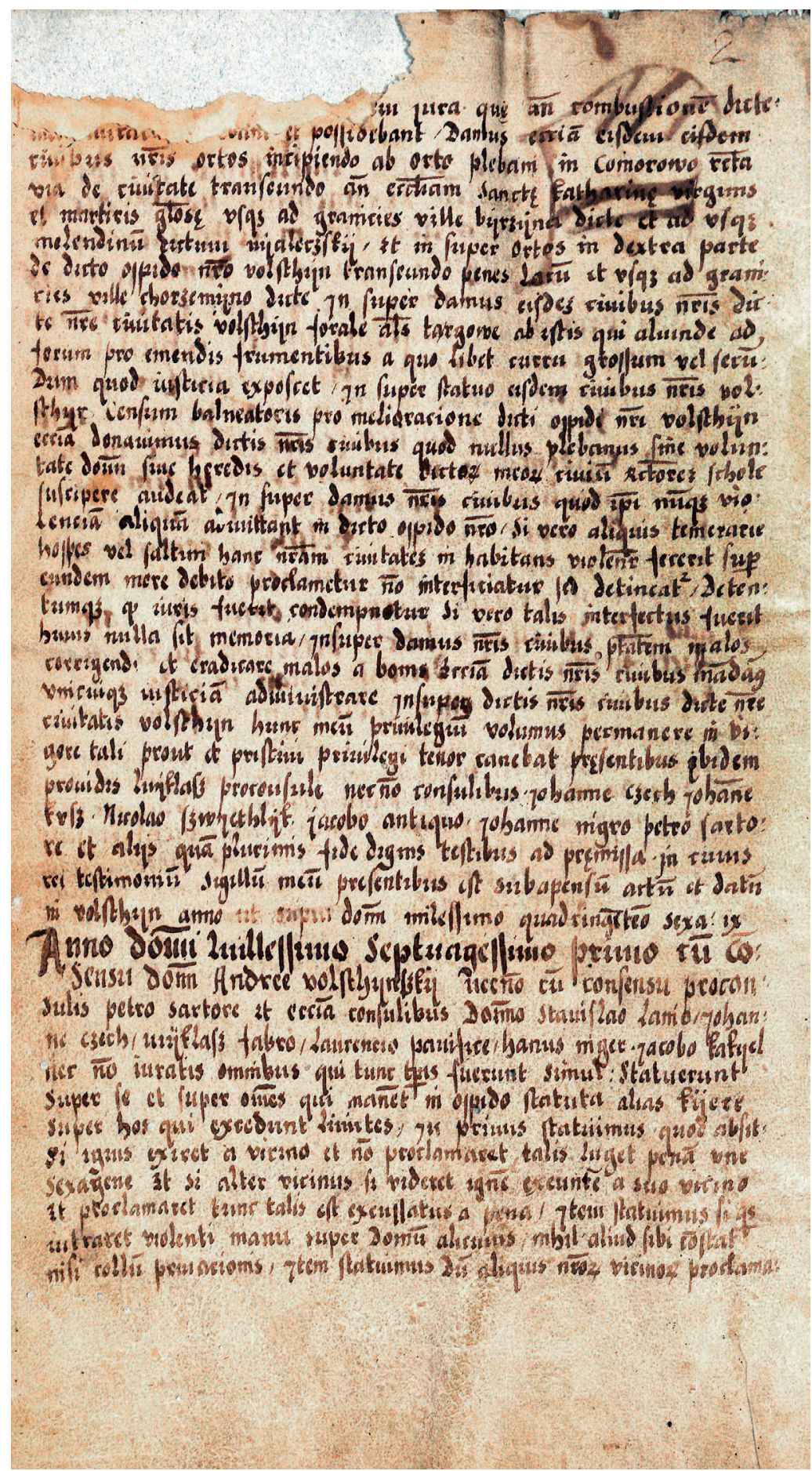

2. Poznań, Archiwum Państwowe, Akta miasta Wolsztyna I/1, k. 2v (dokończenie przywileju dziedzica i początek wilkierza) 
c

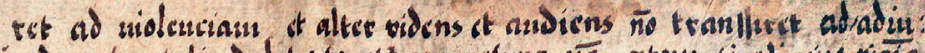

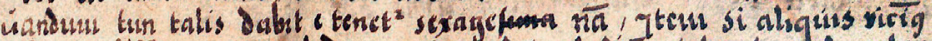

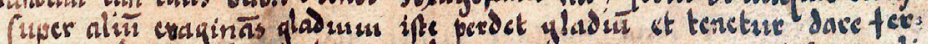

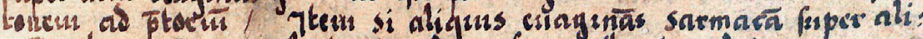

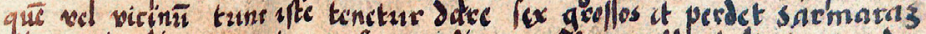

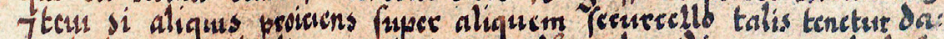

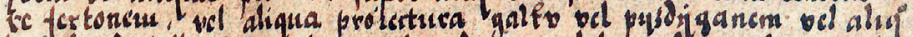

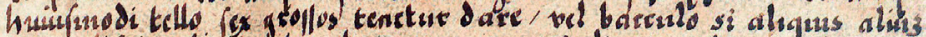

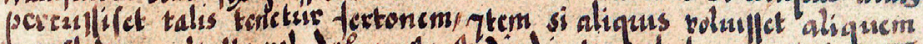

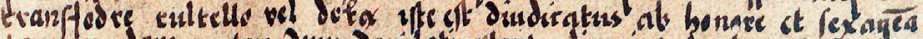

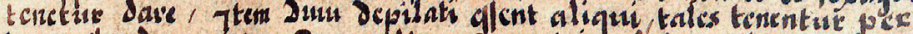

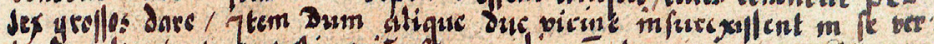

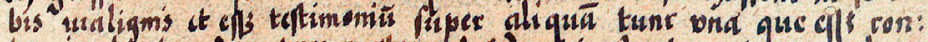

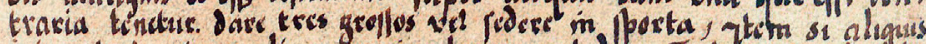

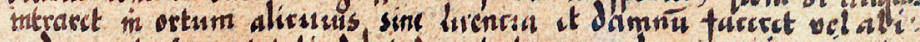

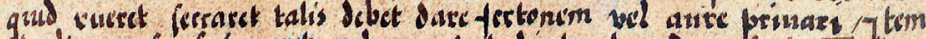

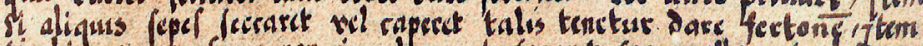

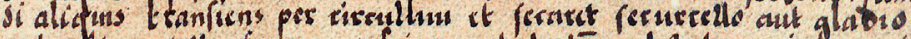
aut alique tollo framina preina out fonté vel fastuas ciera angi

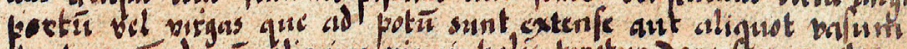

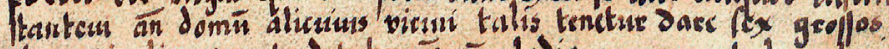

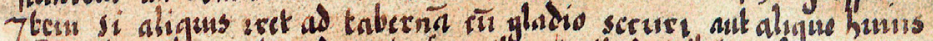

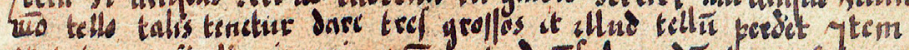

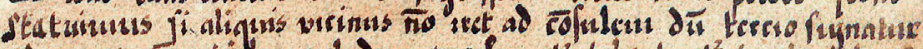

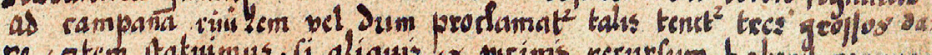

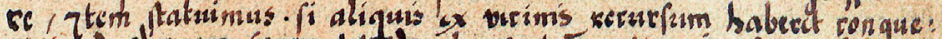

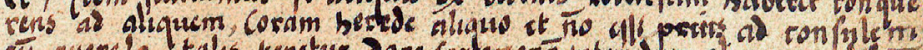

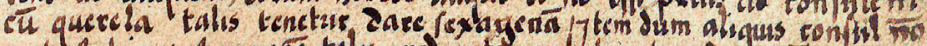

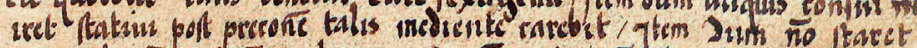

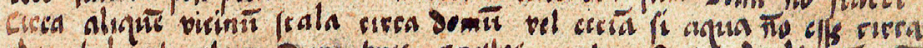

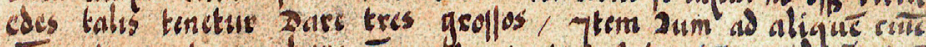

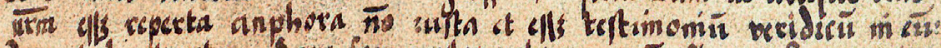

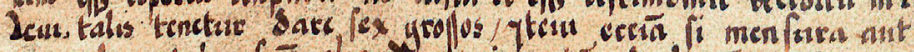

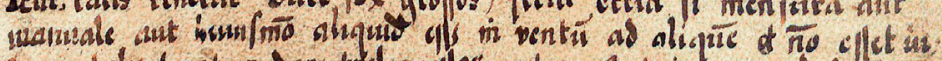

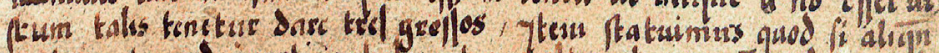

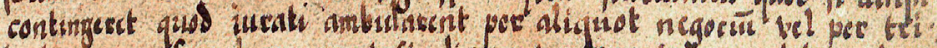

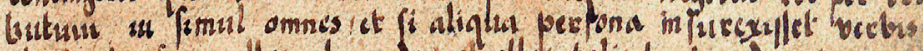

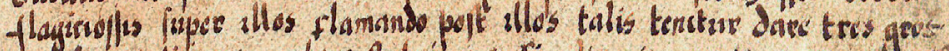

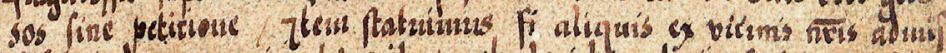

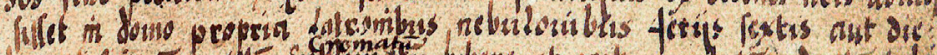

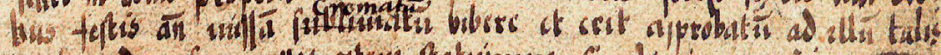

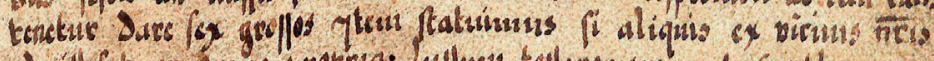

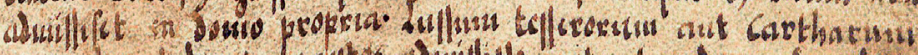

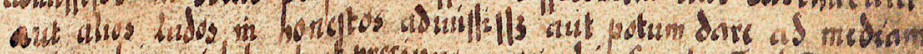

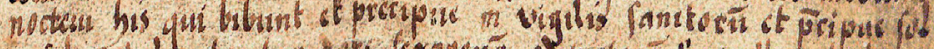

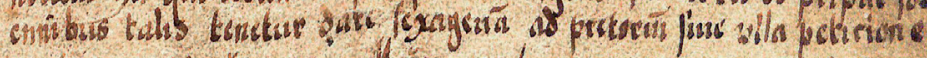

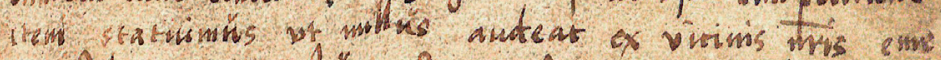

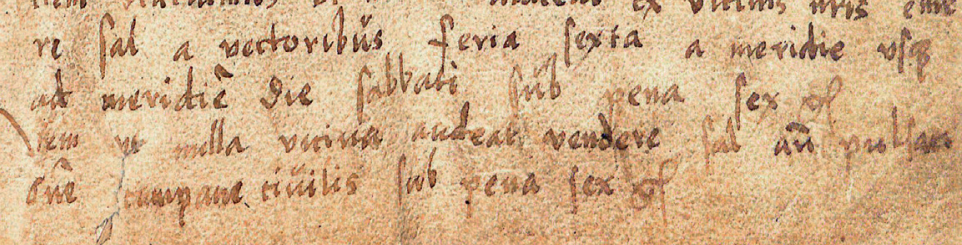

3. Poznań, Archiwum Państwowe, Akta miasta Wolsztyna I/1, k. 3 (dokończenia wilkierza) 